\title{
Učestali leksički spojevi u nastavi engleskog kao stranog jezika struke na master akademskim studijama
}

\author{
Danijela D. Đorđević* \\ Univerzitet u Beogradu, Poljoprivredni fakultet, Kabinet za strane jezike \\ Katarina O. Lazić* \\ Univerzitet u Beogradu, Šumarski fakultet, Katedra opštih predmeta
}

\section{Ključne reči:}

akademski diskurs

engleski jezik struke

nastava stranog jezika struke

master studije razred mešovitog predznanja učestali leksički spojevi

\section{Apstrakt}

Ovo istraživanje se bavi upotrebom učestalih leksičkih spojeva, odnosno celina poput on the other hand 's druge strane' ili are likely to be 'verovatno su', u akademskom diskursu i sposobnošću studenata da ih pravilno upotrebe u određenom kontekstu. Upoznavanje studenata sa akademskim diskursom i njegovim odlikama trebalo bi da zauzima značajno mesto u nastavi stranog jezika struke na fakultetima, a učestali leksički spojevi predstavljaju njegov značajan segment. Jedan način da se studentima pomogne da bolje usvoje strani jezik jeste da vežbaju da uočavaju predmet učenja, a zatim da postanu svesni različitih konteksta u kojima je upotrebljen, kao i funkcija koje obavlja u diskursima akademskih disciplina (Schmidt, 1990). Predmet ovog istraživanja je upotreba učestalih leksičkih spojeva u akademskom diskursu na engleskom jeziku. Ciljevi istraživanja su da se utvrdi da li studenti mogu pravilno da upotrebe učestale leksičke spojeve i da li postoji korelacija između studentskog predznanja engleskog jezika i pravilne upotrebe učestalih leksičkih spojeva. U istraživanju su učestvovali studenti master akademskih studija studijskog programa Poljoprivreda na Poljoprivrednom fakultetu Univerziteta u Beogradu. Rezultati testa pokazuju pravilnu upotrebu određenih učestalih leksičkih spojeva kod pojedinaca koji pripadaju svakoj od grupa različitog predznanja, a njihovu najpravilniju upotrebu kod grupe sa najboljim predznanjem engleskog jezika, čiji se rezultati statistički značajno razlikuju kako od rezultata grupe srednjeg, tako i najlošijeg predznanja, što sugeriše potrebu da se u grupi mešovitog znanja na akademskom nivou više pažnje posveti učestalim leksičkim spojevima i funkcijama koje obavljaju u diskursu date discipline. (примљено: 14. маја 2021; прихваћено: 3. јула 2021) www.anali.fil.bg.ac.rs

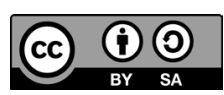

\footnotetext{
Poljoprivredni fakultet Kabinet za strane jezike Nemanjina 6 11080 Zemun, Srbija ddj@agrif.bg.ac.rs
} 


\section{Uvod}

Osim toga što učestali leksički spojevi prožimaju akademski jezik, oni takođe predstavljaju ključni faktor tečne jezičke produkcije (Hyland, 2012), pa bi im svakako trebalo posvetiti pažnju u nastavi stranog jezika struke na fakultetima. Njihovim pravilnim prepoznavanjem i usvajanjem olakšava se usvajanje i ovladavanje diskursom stranog jezika struke, a pre svega njihovo pravilno korišćenje u akademskom pisanju. Učestali leksički spojevi predstavljaju često istraživanu temu, naročito u vezi sa akademskim diskursom.

Predmet ovog istraživanja je upotreba učestalih leksičkih spojeva u akademskom diskursu na engleskom jeziku, a glavni cilj je da se utvrdi da li postoji korelacija između studentskog predznanja engleskog jezika i pravilne upotrebe učestalih leksičkih spojeva u grupi mešovitog znanja. Rezultati istraživanja otkrivaju da li je obrada nastavne jedinice posvećene učestalim leksičkim spojevima bila dovoljna i jednako delotvorna kada su u pitanju studenti lošijeg i boljeg predznanja, a na osnovu rezultata krajnjeg testa koji je bio provera poznavanja ciljnih spojeva. Iako je kod svih grupa zabeleženo poznavanje pojedinih učestalih leksičkih spojeva, u statističkoj analizi se kao značajno uspešnija izdvaja grupa studenata najboljeg predznanja, za koju je nastava jezika struke bila najdelotvornija kada su u pitanju ove celine. U daljem tekstu ćemo razmotriti dosadašnja istraživanja koja su se bavila sličnim problemima, opisati metodologiju ovog istraživanja, a u diskusiji i zaključcima analizirati rezultate kako bismo razmotrili njihove implikacije za dalju primenu učestalih leksičkih spojeva u nastavi.

Ciljevi ovog istraživanja ogledaju se u sledećim istraživačkim pitanjima i hipotezama formulisanim u svetlu dosadašnjih istraživanja koja su se bavila upotrebom učestalih leksičkih spojeva na različitim nivoima kako kompetencije u pisanju, tako i kod izvornih i neizvornih govornika kao manje kompetentnih:

Pitanje 1: Da li postoji korelacija između studentskog predznanja engleskog jezika $i$ pravilne upotrebe učestalih leksičkih spojeva?

$\mathbf{H}_{1:}$ Rezultati testa pravilne upotrebe učestalih leksičkih spojeva nakon obrađene nastavne jedinice koja skreće pažnju na njihovu formu i funkciju će se statistički značajno razlikovati između grupa najboljeg, srednjeg i najslabijeg predznanja.

Pitanje 2: Da li nakon obrađene nastavne jedinice posvećene učestalim leksičkim spojevima studenti mogu pravilno da ih upotrebe?

$\mathbf{H}_{2:}$ Nakon obrađene nastavne jedinice koja skreće pažnju na formu i funkciju učestalih leksičkih spojeva, većina studenata u razredu mešovitog predznanja pokazaće dobro poznavanje upotrebe ciljnih učestalih leksičkih spojeva.

\section{Pojam i termin učestali leksički spoj}

Učestali leksički spojevi su leksičke celine koje najčešće broje tri do šest reči poput the majority of 'veći deo', on the other hand 's druge strane', ili on the basis of 'na osnovu'. Do sada su definisani kao „spojevi reči koji pokazuju statističku tendenciju da se jave zajedno“ (Biber et al., 1999: 989), odnosno „učestali izrazi, bez obzira na njihovu idiomatičnost i strukturni status“ (Biber et al., 1999: 990).

Karakteristike učestalih leksičkih spojeva su učestalost, disperzija, odsustvo idiomatičnosti i specifičan strukturni status. Ovi kriterijumi su preuzeti iz niza dosadašnjih istraživanja (Biber/Barbieri, 2007; Chen/Baker, 2010; Ädel/Erman, 2012). 
Naime, da bi se leksička jedinica kvalifikovala kao učestali leksički spoj, prema dosadašnjim istraživanjima, mora se javiti najmanje 10 puta (Biber et al., 1999) do 40 puta (Biber et al., 2004) u milion reči, i u oko deset posto tekstova istraživanog korpusa, dok ovakve spojeve takođe karakteriše odsustvo idiomatičnog značenja i nepotpun strukturni status, jer nisu vezani za određene gramatičke strukture.

Termin koji se u engleskom jeziku koristi za ovaj pojam je lexical bundle (Biber et al., 1999; Biber et al., 2004), dok je u srpskom u upotrebi termin učestali leksički spoj, s obzirom na to da je osnovna karakteristika koja ih razlikuje od drugih leksičkih spojeva i ustaljenih konstrukcija njihova učestalost. U nastavku ovog rada će se termin učestali leksički spoj upotrebljavati u alternaciji sa skraćenicom ULS.

Osnovne podele učestalih leksičkih spojeva su do sada vršene prema grupama strukturne klasifikacije i funkcionalne taksonomije.

Dosadašnja istraživanja ULS (Cortes, 2004; Bal, 2010; Lazić, 2017) najčešće preuzimaju i neznatno modifikuju strukturni okvir ove klasifikacije iz studije Bajber i dr. (Biber et al., 1999). Na primer, istraživanje Kortes (Cortes, 2004), u kom je izučavana upotreba ULS u tekstovima biologije i istorije, koristi strukturnu klasifikaciju iz studije Bajber i dr. (1999) prilagođenu ciljevima istraživanja, dok je studija Lazić (2017) modifikuje tako da odgovara istraživanju upotrebe ULS u oblasti biotehničkih nauka, kojim pripadaju i poljoprivredne nauke iz kojih su tekstovi našeg istraživanja. Tako se u ovoj strukturnoj klasifikaciji izdvajaju sledeće grupe: imeničke strukture, glagolske strukture, fragmenti sa predloškom frazom i druge strukture (Tabela 1).

\begin{tabular}{|c|c|}
\hline \multicolumn{2}{|c|}{ Strukturna klasifikacija ULS } \\
\hline Grupa 1 & Imeničke strukture (ULS bazirani na imeničkoj frazi) \\
\hline Podgrupa 1 & $\begin{array}{l}\text { Imenička fraza }+ \text { of (engl. Noun phrase }+ \text { of): } \\
\text { Npr. the end of the, a wide range of }\end{array}$ \\
\hline Podgrupa 2 & $\begin{array}{l}\text { Druge imeničke fraze (engl. Other noun phrases): } \\
\text { Npr. the fact that the, an important role in }\end{array}$ \\
\hline Grupa 2 & Glagolske strukture (ULS bazirani na glagolskoj frazi) \\
\hline Podgrupa 1 & $\begin{array}{l}\text { Pasiv }+ \text { fragment sa predloškom frazom (engl. Passive }+ \text { prepositional phrase } \\
\text { fragment): } \\
\text { Npr. is shown in figure, used in this study }\end{array}$ \\
\hline Podgrupa 2 & $\begin{array}{l}\text { Anticipatorno it }+ \text { glagol/pridev (engl. Anticipatory it }+ \text { verb/adj.): } \\
\text { Npr. it is important to, it should be noted }\end{array}$ \\
\hline Podgrupa 3 & $\begin{array}{l}\text { Be }+ \text { imenica/ pridevska fraza (engl. Be+ noun/adjectival phrase): } \\
\mathrm{Npr} \text {. is the same as, is a function of }\end{array}$ \\
\hline Grupa 3 & Fragmenti sa predloškom frazom (ULS bazirani na predloškoj frazi) \\
\hline Podgrupa 1 & $\begin{array}{l}\text { Predloška fraza }+ \text { of (engl. Prepositional phrase }+ \text { of): } \\
\text { at the end of, as a result of, on the basis of, in the context of }\end{array}$ \\
\hline Podgrupa 2 & $\begin{array}{l}\text { Druge predloške fraze (engl. Other prespositional phrases): } \\
\text { on the other hand, at the same time, in the present study, with respect to the }\end{array}$ \\
\hline Grupa 4 & $\begin{array}{l}\text { Druge strukture } \\
\text { Druge strukture (eng. Others): } \\
\text { Npr. should be noted that, are likely to be }\end{array}$ \\
\hline
\end{tabular}

Tabela 1. Strukturna klasifikacija ULS iz biotehničkih tekstova prema Lazić (2017) 
Funkcionalna klasifikacija se u većini dosadašnjih studija preuzima iz rada Hajland (Hyland, 2008b), koji analizira karakteristike upotrebe ULS u tekstovima prirodnih nauka, koje su srodne biotehničkim naukama čiji su testovi korišćeni u ovom istraživanju. Studije Salazar (2011) i Lazić (2017) sadrže prilagođenu verziju funkcionalne taksonomije iz studije Hajland (2008b), koja obuhvata ULS orijentisane ka istraživanju sa podgrupama za mesto, proceduru, kvantifikaciju i opis, ULS orijentisane ka tekstu sa podgrupama tranzicioni, rezultativni, strukturni i ograničavajući signali i ULS orijentisane ka govorniku sa podgrupama ULS stava i ULS uključivanja (Tabela 2).

\begin{tabular}{|c|c|}
\hline Grupa 1 & ULS orijentisani ka istraživanju \\
\hline Podgrupa 1 & $\frac{U L S z a \text { mesto/vreme }}{\text { Npr. the end of the, the top of the, at the time of }}$ \\
\hline Podgrupa 2 & $\frac{U \boldsymbol{U S} \boldsymbol{Z} \text { za proceduru }}{\text { Npr. as a function of the, can be used to }}$ \\
\hline Podgrupa 3 & $\frac{U L S \boldsymbol{z} \text { a } \text { kvantifikaciju }}{\text { Npr. a wide range of, the total number of }}$ \\
\hline Podgrupa 4 & $\frac{U \boldsymbol{U L S} \text { za opis }}{\text { Npr. the quality of the, has the potential to }}$ \\
\hline Grupa 2 & ULS orijentisani ka tekstu \\
\hline Podgrupa 1 & $\frac{\text { Tranzicioni signali }}{\text { Npr. on the other hand, in addition to the }}$ \\
\hline Podgrupa 2 & $\frac{\text { Rezultativni signali }}{\text { Npr. has been shown to, as a result of }}$ \\
\hline Podgrupa 3 & $\frac{\text { Strukturni signali }}{\text { Npr. are shown in figure, are shown in Table, in this study we }}$ \\
\hline Podgrupa 4 & $\begin{array}{l}\text { Ograničavajuci signali } \\
\text { Npr. is based on the, in the case of, in terms of the }\end{array}$ \\
\hline Grupa 3 & ULS orijentisani ka učesniku \\
\hline Podgrupa 1 & $\frac{\text { ULS Stava }}{\text { Npr. are likely to be, is likely to be }}$ \\
\hline Podgrupa 2 & $\frac{\text { ULS ukliucivanja }}{\text { Npr. it is important to, it should be noted }}$ \\
\hline
\end{tabular}

Tabela 2. Funkcionalna taksonomija ULS iz biotehničkih tekstova prema Lazić (2017)

\section{Pregled literature}

3.1. Učestali leksički spojevi u akademskom diskursu i pisanju

Istraživanje opisano u ovom radu ispituje upotrebu ULS u tekstovima koji pripadaju domenu akademskog diskursa i nadovezuje se na niz dosadašnjih istraživanja koja su često isticala njihov značaj u ostvarivanju komunikativnih funkcija $u$ akademskom govoru i pisanju. Zato se najpre ukratko osvrćemo na ona koja ističu značaj upotrebe ULS za akademski diskurs uopšte, a u sledećem odeljku navodimo i ona koja konkretnije govore o nepoklapanjima u upotrebi ULS između konverzacije i akademske proze. 
Veliki značaj učestalih leksičkih spojeva za akademski diskurs prepoznaje Hajland (2008a), koji vidi njihovu bogatu i adekvatnu upotrebu kao doprinos koherentnosti teksta, modelovanju značenja u specifičnim kontekstima, te stoga smatra da predstavljaju značajan segment tečne jezičke produkcije u akademskoj sferi.

Jedno od važnih istraživanja koje ispituje učestale leksičke spojeve u akademskom pisanju je studija Bajber i dr. (2004), koja se bavi nizovima od više reči u predavanjima i udžbenicima, odnosno dva važna univerzitetska registra.

Učestali leksički spojevi su bitan činilac akademskog žanra, a akademski tekstovi se odlikuju posebnim karakteristikama upotrebe ULS. Zato, Bajber i dr. (1999) vrše poređenje različitih registara i pronalaze znatnu upotrebu ULS kako u akademskoj konverzaciji, tako i u prozi.

\subsection{Učestali leksički spojevi u konverzaciji i akademskoj prozi}

Posebno interesantnim se čini uvid u to u čemu se ogledaju nepoklapanja između konverzacije i akademske proze, s obzirom na to da je poznavanje upotrebe ULS jednako važno za studente u oba navedena registra. Bajber (Biber, 2009) uočava da se ULS u pisanju pojavljuju u okviru obrazaca čiji delovi variraju, dok u konverzaciji dominiraju fiksni nizovi reči. U nizu istraživanja, autori (Biber/Conrad, 1999; Biber et al., 1999; Biber et al., 2003, 2004; Biber/Barbieri, 2007) uočavaju nepoklapanje između konverzacije i akademske proze, kada je u pitanju raspodela ULS po grupama strukturne i funkcionalne klasifikacije. Na primer, dok je većina ULS u konverzaciji klauzalnog tipa, u akademskoj prozi ULS su uglavnom frazalnog tipa. Bajber i Konrad (Biber/Conrad, 1999) pronalaze da se strukture ULS u gramatičkom smislu bitno razlikuju između konverzacije i akademske proze. Dok kod konverzacije 90\% svih spojeva predstavljaju deklarativne ili upitne segmente klauza, oko 50\% njih počinje kombinacijom lične zamenice i glagolske fraze (npr. I don't know why 'ne znam zašto' ili I thought that was 'mislio sam da je to bio'). Za razliku od toga, preko 60\% svih ULS u akademskoj prozi predstavljaju delove imeničkih ili predloških fraza (npr. the nature of the 'priroda' ili as a result of 'kao rezultat'). U konverzaciji većina ULS sadrži ličnu zamenicu u kombinaciji sa glavnim glagolom koji se koristi da se započne iskaz i iskaže stav (npr. glagoli think 'misliti', know 'znati', ili want 'želeti'), što se dopunjava that-klauzom, to-klauzom ili WH-klauzom (npr. I didn't know what she's got 'nisam znao šta ima'). Za razliku od većine ULS u konverzaciji, koji se sastoje of klauzalnih elemenata, ULS $u$ akademskoj prozi su najčešće frazalni $i$ sadrže elemente imeničke ili predloške fraze (npr. the plant draws its nutrients from the surface of the soil 'Biljka crpi hranljive materije sa površine zemljišta').

Bajber i Barbieri (Biber/Barbieri, 2007) su nešto konkretnije istražili učestale leksičke spojeve u govornim i pisanim univerzitetskim registrima, pri čemu su uočili nepoklapanja između njihovih primarnih funkcija. Dok, kao i Bajber i Konrad (1999), pronalaze da se kod govornih registara učestali leksički spojevi najčešće koriste za izražavanje stava govornika (npr. I don't want to 'ne želim'), u pisanim dominira njihova referencijalna funkcija u spojevima koji ukazuju na određeni predmet, ideju, mesto ili funkciju (npr. at the same time 'u isto vreme' ili those of you who 'oni među vama koji'). 
Iako je istraživanje opisano u ovom radu rađeno na ULS koji potiču samo iz akademskog pisanja, značaj gore navedenih studija je u tome što nam ukazuju na specifičnost upotrebe ULS u konverzaciji kao pravac u kome bi se naša istraživanja mogla nastaviti.

\subsection{Učestali leksički spojevi i tekstovi različitih disciplina}

U korpusnim studijama koje se usredsređuju na engleski za akademske namene učestali leksički spojevi često skreću pažnju istraživača, a posebno kada je u pitanju specifičnost njihove upotrebe vezana za određenu naučnu disciplinu, koja svakako odlikuje i tekstove iz oblasti šumarstva i poljoprivrede. Naše istraživanje je jedno od retkih koje se usredsređuje na upotrebu ULS u tekstovima biotehničkih nauka na engleskom jeziku, a nadovezuje se na mnoštvo prethodnih studija koje su izučavale upotrebu ULS u nizu naučnih disciplina. Značaj istraživanja koja su opisana u ovom odeljku za našu studiju je u tome što nam daju uvid u meru u kojoj upotreba ULS varira zavisno od discipline, i zato dajemo kratak pregled njihovih najzanimljivijih nalaza.

Hajland (2008b) se do sada pozabavio posebnim karakteristikama upotrebe ULS kod pojedinih naučnih disciplina, i pronalazi brojna nepoklapanja u njihovoj upotrebi između tekstova primenjene lingvistike i poslovne ekonomije, ili tekstova prirodnih nauka poput elektrotehnike i biologije. Tekstovi ovih disciplina dolaze iz nauka koje su donekle približnije biotehničkim iz kojih su ULS analizirani u ovom istraživanju.

Kada su različite naučne oblasti u pitanju, autori raspolažu specifičnim sredstvima kojima iznose argumente i pridobijaju poverenje čitalaca dok zagovaraju neku ideju (Hyland, 2008b). Takođe, isti autor beleži da se sa spiska 50 najučestalijih ULS iz jedne discipline jedva jedna polovina njih može pronaći u tekstovima neke druge oblasti.

Jezičke odlike svojstvene tekstovima određene discipline često pokazuju specifičnost, pa se smatra da nije najbolje rešenje za studente upotrebiti neki uopšten nastavni materijal, već da je daleko bolje pružiti im mogućnost da razumeju odlike upravo onog diskursa na koji će naići u pojedinim kursevima. Još jedna stvar koju predlaže Hajland (2008b) je da se buduća istraživanja više pozabave analizom žanra koja je ključna za razumevanje načina na koji autori koriste engleski u nizu akademskih konteksta.

Značajno istraživanje koje se takođe usredsređuje na upotrebu ULS u različitim naučnim disciplinama je studija Kortes (2004), koja upoređuje ULS kod univerzitetskih studenata koji su izvorni govornici i njihovu upotrebu kod afirmisanih autora u člancima objavljenim u oblasti biologije i istorije, a iznenađujući nalaz je da studenti retko koriste ULS zabeležene u objavljenim radovima.

Još jedna studija koja analizira ULS u tekstovima koji pripadaju različitim oblastima je Berd i Kokshed (Byrd/Coxhead, 2010). Ovo istraživanje se usredsređuje na četvoročlane ULS u tekstovima nauke, trgovine, prava i umetnosti, analizirajući akademsko pisanje i objavljenu građu koja se bavi istom problematikom. 


\subsection{Različiti nivoi kompetencije i upotreba učestalih leksičkih spojeva}

Mnoštvo studija istražuje učestale leksičke spojeve u akademskom pisanju upoređivanjem dela autora različitih nivoa kompetencije u pisanju na engleskom, ili autora koji su neizvorni govornici engleskog sa pisanjem onih kojima je taj jezik maternji. Istraživanje opisano u ovom radu se nadovezuje na oba tipa studija, jer izučava upotrebu ULS iz tekstova izvornih govornika kod neizvornih govornika engleskog, a sa druge upotrebu ULS koje koriste afirmisani autori u oblasti biotehnike kod studenata koji tek savlađuju veštinu pisanja na engleskom jeziku.

Dosadašnji napori u istraživanjima bili su usmereni na poređenja upotrebe učestalih leksičkih spojeva kod izvornih govornika engleskog jezika i onih kojima je engleski L2, kada pišu naučne radove na engleskom jeziku, npr. studija Epel i Mari (Appel/Murray, 2020). Neke od takvih su i sledeće studije koje se usredsređuju na učestale leksičke spojeve kod izvornih govornika engleskog u poređenju sa njihovom upotrebom kod govornika kojima maternji jezik nije engleski već kineski (Chen/Baker, 2010; Bychkovska/Lee, 2017), švedski (Ädel/Erman, 2012), češki (DontschevaNavratilova, 2012) ili srpski jezik (Lazić, 2017).

Podudarno otkriće istraživanja Čen i Bejker (2010) i Edel i Erman (2012) je da neizvorni govornici upotrebaljavaju ograničen skup učestalih leksičkih spojeva, dok tekstovi akademskih stručnjaka koji su i izvorni govornici engleskog $i$ afirmisani autori koji često objavljuju sadrže daleko veći broj ULS, koji takođe imaju tendenciju da budu raznovrsniji.

Posebnu kategoriju u ovakvim istraživanjima čine studije koje porede upotrebu ULS kod iskusnih stručnjaka koji često objavljuju tekstove u nauci i onih koji su tek u procesu ovladavanja veštinom akademskog pisanja. Jedno od prvih istraživanja u toj oblasti je studija Kortes (2002) koja se usredsređuje na učestale leksičke spojeve u esejima studenata prve godine, za koje utvrđuje da se u značajnoj meri funkcionalno razlikuju kod onih koji tek savlađuju veštinu pisanja i iskusnijih autora. U još jednom istraživanju, Kortes (2004) izučava studentsko pisanje kod izvornih govornika i poredi ga sa naučnim člancima iz časopisa, pri čemu pronalazi da studenti najčešće upotrebljavaju one ULS koji se ne koriste u objavljenim tekstovima, a čak i kada upotrebe neki od tih spojeva, koriste ih različito od afirmisanih autora sa velikim iskustvom u pisanju i objavljivanju. Još jedno interesantno istraživanje je studija Hajland (2008a) koja analizira učestale leksičke spojeve u naučnim člancima, doktorskim disertacijama i master radovima, i utvrđuje da se dešava da studenti master studija koji su neizvorni govornici engleskog, teže da upotrebljavaju veći broj ULS čak i od iskusnih autora, kako bi pružili dokaz svoje kompetencije. Jedno od bitnih zapažanja ove studije je da ULS pomažu oblikovanju značenja u specifičnim kontekstima i doprinose koherentnosti teksta.

Kao i gore navedena istraživanja, i ova studija se bavi ispitivanjem upotrebe ULS kod studenata koji su neizvorni govornici engleskog, dok je novina to što se poređenje vrši unutar grupe studenata mešovitog znanja, a između grupa studenata različitog predznanja engleskog jezika, a ne sa radovima afirmisanih autora. Na taj način, u odnosu na dosadašnje studije, ovo istraživanje produbljuje analizu upotre- 
be ULS kod onih koji uče engleski jezik, ispitujući razliku u postignućima između podgrupa različitog predznanja u okviru kursa stranog jezika u kom svi studenti savlađuju engleski kao strani jezik struke.

Ciljevi ovog istraživanja su bili da se utvrdi:

1. da li je predznanje studenata povezano sa pravilnom upotrebom učestalih leksičkih spojeva i

2. da li nakon obrađene nastavne jedinice posvećene učestalim leksičkim spojevima studenti mogu pravilno da ih upotrebe.

Imajući sve navedeno u vidu, sproveli smo istraživanje, i u nastavku ćemo izložiti njegovu metodologiju.

\section{Metodologija istraživanja}

Istraživanje je sprovedeno među studentima master akademskih studija, studijskog programa Poljoprivreda (moduli: Ratarstvo i povrtarstvo, Hortikultura, Upravljanje zemljištem i vodama, Zootehnika, Biotehnički i informacioni inženjering i Organska poljoprivreda) na Poljoprivrednom fakultetu Univerziteta u Beogradu školske 2020/2021. godine koji su pohađali kurs Engleski jezik sa fondom od pet časova nedeljno. Na početku kursa Engleski jezik, studenti su uradili ulazni test (engl. placement test) kako bi se utvrdio njihov nivo poznavanja engleskog jezika (A1-C2). Imajući u vidu rezultate testa, radi lakše obrade podataka, studenti su potom podeljeni u tri grupe: I (A1/A2), II (B1) i III (B2/C1). Do kraja prvog semestra, 58 studenata (od ukupno 96 prijavljenih) uradilo je i ulazni test i deo svojih predispitnih obaveza koji je uključivao proveru upotrebe učestalih leksičkih spojeva.

Tokom nastave, studentima je eksplicitno ukazano na važnost ULS koji se sreću u akademskom diskursu, navođenjem različitih primera zasebno, kao i na konkretnim primerima iz naučnog rada (npr. as a result of 'kao rezultat' in the case of ' $u$ slučaju' are/is shown in 'kao što se pokazalo u', a large number of 'veliki broj' is likely to be 'verovatno je', as a function of 'u funkciji', are likely to be 'verovatno su' itd.) ${ }^{1}$, ukazivanjem na različite funkcije ovih leksičkih spojeva. Studenti su zatim uvežbavali prepoznavanje i upotrebu ULS. Vežbanja su se sastojala od prepoznavanja i obeležavanja učestalih leksičkih spojeva na primeru naučnih radova, određivanja funkcije obeleženih ULS u datim kontekstima, i pisanju pojedinih delova naučnog rada uzimajući u obzir i upotrebu ULS. Na kraju kursa, studenti su, u okviru svojih predispitnih obaveza, imali zadatak da popune praznine datim učestalim leksičkim spojevima, odnosno da ih pravilno upotrebe, čime je testirana pravilna upotreba ULS. Zadatak se sastojao od 15 rečenica gde je trebalo da se studenti opredele za jedan tačan odgovor (engl. multiple-choice), odnosno za odgovorajući učestali leksički spoj. U navedenom zadatku su bili upotrebljeni sledeći učestali leksički spojevi: be due to, the results of the, on the basis of, at the end of, on the other hand, as well as the, with the exception of, a wide range of, was used to determine, are likely to be, the efficiency of the, as a function of, it should be noted, can be used to, at a rate of.

1 Primeri za upoznavanje studenta sa učestalim leksičkim spojevima uzimani su iz korpusa tekstova afirmisanih autora biotehničkih naučnih članaka i izvornih govornika engleskog iz studije Lazić (2017). 
Sledeća aktivnost koju smo preduzeli u analizi dobijenih rezultata bilo je ispitivanje korelacije između predznanja i pravilne upotrebe učestalih leksičkih spojeva. Za potrebe ovog dela analize, rezultati bodovanja usvojenih ULS razvrstani su u tri grupe, odnosno one koje pripadaju grupi najlošijeg predznanja (nivo A1/A2), zatim grupi srednjeg predznanja (nivo B1) i najboljeg predznanja (nivo B2/C1). Cilj je bio da se ispita da li se obrađenom nastavnom jedinicom posvećenom ULS tokom kursa engleskog jezika struke na master akademskim studijama postiže jednak efekat kod sve tri grupe studenata, ili se neka od njih izdvaja u odnosu na druge. Iako je najlogičnije da studenti najboljeg predznanja pravilnije upotrebljavaju ULS koji karakterišu akademski diskurs date discipline, i koji su generalno zastupljeniji i raznovrsniji u upotrebi kod govornika na višim nivoima kompetencije, želeli smo da ispitamo da li se između grupa različitog predznanja javila i statistički značajna razlika u pravilnoj upotrebi ciljnih ULS. Za potrebe statističke analize razlika između tri grupe studenata koristili smo jednofaktorsku analizu varijanse (ANOVA) za ispitivanje uticaja jedne promenljive, odnosno studentskog predznanja na jednu zavisnu promenljivu, odnosno pravilnu upotrebu ULS.

\section{Rezultati i diskusija}

U ovom odeljku ćemo se osvrnuti na rezultate sprovedenog istraživanja imajući u vidu dva osnovna cilja. U prvom delu pažnju ćemo usmeriti na to koliko su studenti pravilno upotrebili ULS, dok ćemo se u drugom delu osvrnuti na moguće koreliranje između predznanja engleskog jezika studenta i pravilne upotrebe učestalih leksičkih spojeva.

\subsection{Pravilna upotreba učestalih leksičkih spojeva}

Kao što je navedeno u pregledu literature, dosadašnja istraživanja su se bavila poređenjem ULS na različitim nivoima kompetentnosti, npr. poređenjem njihove upotrebe kod izvornih i neizvornih govornika, a zatim i kod afirmisanih autora, $\mathrm{u}$ doktorskim disertacijama i master tezama. Naša studija se nastavlja na ova istraživanja usredsređujući se samo na nivo master akademskih studija.

Kao što se iz grafikona 1 može videti, svi studenti su pojedinačno pokazali poznavanje ciljnih ULS posle obrađene nastavne jedinice posvećene ovim spojevima, jer nije bilo onih koji nisu pokazali poznavanje nijednog od ispitivanih ULS, već su i pojedinačno prepoznali najmanje četiri od 15 ULS. Samo jedan student je pravilno upotrebio svih 15 učestalih leksičkih spojeva.

Kada u obzir uzmemo učestale leksičke spojeve, najveći procenat studenata (95\%) pravilno je upotrebio ULS at a rate of 'pri stopi od', koji pripada strukturnoj grupi fragmenti sa predloškom frazom i funkcionalnoj grupi ULS orijentisani ka istraživanju (podgrupa za kvantifikaciju), kao i the results of the 'rezultati' (90\%), koji pripada imeničkim frazama sa of, i, u funkcionalnom smislu, ULS orijentisanim ka tekstu (podgrupa rezultativni signali).

Nasuprot tome, kod oko jedne trećine studenata (33\%) podjednako su najmanje pravilno usvojeni as well as the 'kao i' iz strukturne grupe druge strukture, i funk- 
cionalne grupe ULS orijentisani ka tekstu (podgrupa tranzicioni signali), kao i are likely to be 'verovatno su' koji pripada drugim strukturama, a funkcionalno ULS orijentisanim ka učesniku (podgrupi ULS stava).

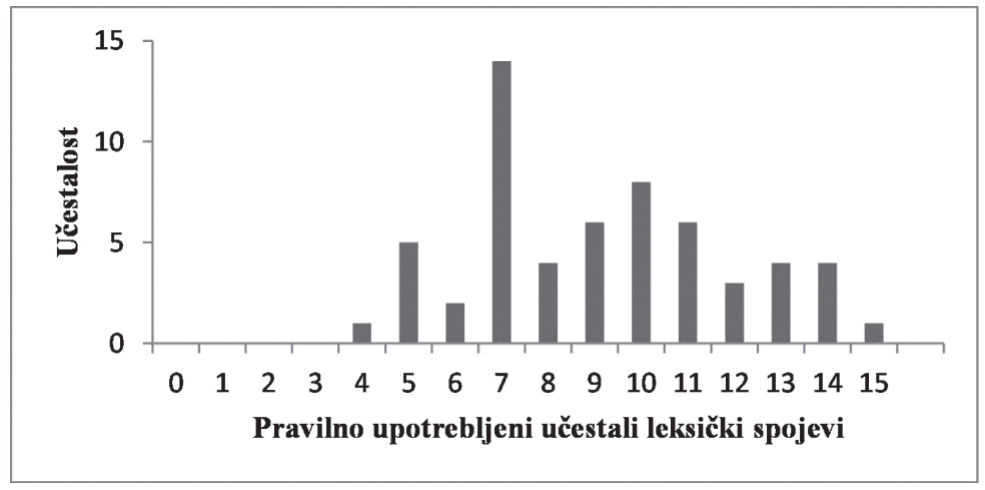

Grafikon 1. Distribucija pravilno upotrebljenih učestalih leksičkih spojeva

Ipak, uočeno je da pojedini studenti dobrog predznanja pokazuju poznavanje većine zadatih ULS (13-15), što nas je podstaklo da istražimo da li grupa studenata sa najboljim predznanjem pokazuje i statistički značajno bolje rezultate u pravilnoj upotrebi ULS.

Kada su u pitanju konkretni ULS, uočeno je da su ULS koje je pravilno upotrebio najveći broj studenata at a rate of $\mathrm{i}$ the results of the spojevi koji se u korpusu biotehničkih naučnih članaka izvornih govornika engleskog CoBNEA iz studije Lazić (2017) javljaju sa umerenom učestalošću od 20 puta (at a rate of ) i 29 puta (the results of the) u milion i po reči.

Nasuprot tome, najmanje uspešno usvojeni ULS as well as the i are likely to be, se u korpusu biotehničkih naučnih članaka izvornih govornika pomenutog istraživanja javljaju sa visokom učestalošću od čak 113 i 44 puta u milion i po reči. Objašnjenje za ovakav nalaz može biti to što su ULS čija je upotreba testirana preuzeti iz korpusa biotehničkih naučnih članaka afirmisanih autora i izvornih govornika engleskog, dok Kortes (2004) pronalazi da i studenti koji su izvorni govornici engleskog, retko koriste ULS prepoznate u korpusu objavljenih tekstova, a čak i kada ih koriste, čine to na drugačiji način u odnosu na iskusne autore.

5.2. Korelacija između studentskog predznanja engleskog jezika i pravilne upotrebe ULS

Izučavanje upotrebe ULS na master akademskim studijama se produbljuje ispitivanjem razlike u upotrebi ULS između podgrupa različitog predznanja engleskog jezika, koje pripadaju ovoj grupi mešovitog znanja stranog jezika (engl. mixed-ability class). Nasuprot tome što Hajland (2008a) pronalazi da studenti master studija, iako neizvorni govornici engleskog, veoma često koriste ULS, pa čak i više od afirmisanih stručnjaka, kako bi dokazali svoju kompetentnost, mi pronalazimo upotrebu 
USL koja je na adekvatnom nivou samo kod studenata sa najboljim predznanjem engleskog jezika, a znatno lošiji rezultat kod studenata slabijeg predznanja može da potiče od nedovoljne primene vežbanja koja su posvećena ULS tokom kursa stranog jezika struke ili njihove neadekvatne razrađenosti da bi se kod svih grupa studenata u razredu mešovitog predznanja ostvario ciljni efekat.

Nakon sprovedene statističke analize pomoću jednofaktorske analize varijanse (ANOVA $)^{2}$, nulta hipoteza da ne postoji razlika u pravilnoj upotrebi ULS između grupa različitog predznanja engleskog jezika je odbačena $(p<0,05 ; p=0,000011$; $F=14,229$ ), a daljom analizom pomoću Post Hoc Tukey's HSD testa međusobno su upoređeni rezultati svake od grupa sa svakom (Tabele 3 i 4).

\begin{tabular}{|l|l|l|l|l|}
\hline \multicolumn{5}{|c|}{ Rezultati } \\
\hline Izvor & $S S$ & $d f$ & $M S$ & \\
\hline Između grupa & 150,5616 & 2 & 75,2808 & $F=\mathbf{1 4 , 2 2 9 5 8}$ \\
\hline Unutar grupe & 285,684 & 54 & 5,2904 & \\
\hline Ukupno & 436,2456 & 56 & & \\
\hline
\end{tabular}

Tabela 3. Rezultati jednofaktorske analize varijanse ANOVA

\begin{tabular}{|l|l|l|l|}
\hline \multicolumn{2}{|c|}{$\begin{array}{c}\text { Poređenje svake grupe sa } \\
\text { svakom }\end{array}$} & $\begin{array}{l}\mathrm{HDS}_{, 05}=2,4263 \\
\mathrm{HDS}_{, 01}=3,0618\end{array}$ & $\mathrm{Q}_{005}=3,4082 \quad \mathrm{Q}_{.01}=4,3008$ \\
\hline $\mathbf{T}_{\mathbf{1}}: \mathbf{T}_{\mathbf{2}}$ & $\begin{array}{l}\mathrm{M}_{1}=8,11 \\
\mathrm{M}_{2}=10,06\end{array}$ & 1,94 & $\mathrm{Q}=2,73(p=, \mathbf{1 3 9 7 1 )}$ \\
\hline $\mathbf{T}_{\mathbf{1}}: \mathbf{T}_{\mathbf{3}}$ & $\begin{array}{l}\mathrm{M}_{1}=8,11 \\
\mathrm{M}_{2}=13,60\end{array}$ & 5,49 & $\mathbf{Q}=\mathbf{7 , 7 1}(p=, 00000)$ \\
\hline $\mathbf{T}_{\mathbf{2}}: \mathbf{T}_{\mathbf{3}}$ & $\begin{array}{l}\mathrm{M}_{2}=10,06 \\
\mathrm{M}_{3}=13,60\end{array}$ & 3,54 & $\mathbf{Q}=\mathbf{4 , 9 7}(p=, 00253)$ \\
\hline
\end{tabular}

Tabela 4. Rezultati Post Hoc Tukey's HSD testa

Statistički značajno različiti rezultati između grupe najlošijeg i najboljeg predznanja $(Q=7,71)$ i između grupe srednjeg i najboljeg predznanja $(Q=4,97)$ nam sugerišu da su nastavne jedinice obrađene u toku kursa stranog jezika na master akademskim studijama imale najviše efekta za studente na najvišem nivou kompetencije. Ovakav nalaz je razumljiv s obzirom na to da je bogata i raznovrsna upotreba ULS najčešće odlika izražavanja autora na najvišim nivoima kompetencije u pisanju kojom doprinose oblikovanju značenja u specifičnim kontekstima i koherentnosti teksta (Hyland, 2008a). Studenti slabijeg i srednjeg predznanja čine većinu u grupi mešovitog znanja i zato smatramo da su tipičniji predstavnici studentske populacije od malog broja studenata koji su se izdvojili izuzetno dobrim predznanjem engleskog. Između rezultata grupa najlošijeg i srednjeg predznanja nije bilo statistički značajne razlike u pravilnoj upotrebi ciljnih ULS $(Q=2,73)$, dok su statistički značajno lošiji od rezultata studenata na najvišem nivou jezičke kompetencije. Ovakav

2 Za potrebe statističke analize podataka je korišćen onlajn kalkulator Social Science Statistics, One-Way ANOVA calculator, including Tukey HSD https://www.socscistatistics.com/tests/anova/default2.aspx 
rezultat dobijen za prosečnog studenta koji je neizvorni govornik engleskog je u skladu sa zajedničkim nalazom studija Čen i Bejker (2010) i Edel i Erman (2012) da neizvorni govornici koriste ograničen repertoar ULS. Osim toga, objašnjenje može biti to što su ULS čija je upotreba testirana preuzeti iz korpusa biotehničkih naučnih članaka afirmisanih autora i izvornih govornika engleskog, a Kortes (2004) čak i kod studenata koji su izvorni govornici engleskog utvrđuje da retko koriste ULS iz objavljenih tekstova.

\section{Zaključna razmatranja}

Ovo istraživanje imalo je za cilj da pokaže da li studenti pravilno upotrebljavaju učestale leksičke spojeve. Takođe, nastojali smo da utvrdimo da li postoji korelacija između studentskog predznanja engleskog jezika i pravilne upotrebe učestalih leksičkih spojeva, a naši nalazi daju delimično potvrdan odgovor na postavljena istraživačka pitanja i potvrđuju jednu od postavljenih hipoteza, dok za drugu predlažu smer u kome bi se empirijska istraživanja mogla nastaviti.

Pronađena korelacija između studentskog predznanja engleskog jezika i pravilne upotrebe ULS dala je potvrdan odgovor na prvo istraživačko pitanje, a po statistički značajnoj razlici u pravilnoj upotrebi ULS izdvojila se grupa najboljeg predznanja, što je potvrdilo postavljenu hipotezu $\mathrm{H}_{1}$. Rezultati našeg istraživanja ukazuju na to da se primena nastavne jedinice koja pažnju studenata usmerava na ove spojeve mora prilagoditi razredu mešovitog znanja, kako bi proizvela pravilniju upotrebu ULS kod studenata srednjeg i najlošijeg predznanja. Tačnije, nalaz našeg istraživanja koji nam ukazuje na to da su vežbanja rađena tokom kursa stranog jezika struke na master akademskim studijama bila značajno manje delotvorna za studente srednjeg i najlošijeg predznanja takođe sugeriše da bi veći broj vežbanja tokom kursa trebalo posvetiti ULS kroz podizanje svesti o njihovoj upotrebi i upoznavanje sa njihovom formom i funkcijom, ali i njihovom eksplicitnom učenju kroz upotrebu ovih spojeva u produktivnim zadacima, kao što je pisanje rečenica ili pasusa. Kako Hajland (2008a) i Kortes (2004) u zaključcima svojih studija navode, izrada i primena vežbi koje skreću pažnju na ULS, kao i produktivne vežbe koje podstiču one koji uče da ih upotrebe, mogu pomoći da ove formulaične jedinice, sastavljene od nekoliko reči uvedu u pisanje. Osim toga što je vežbe na nivou prepoznavanja ULS potrebno dopuniti eksplicitnim učenjem kroz znatno zahtevniju upotrebu u produktivnim zadacima pisanja, svim studentima, bez obzira na nivo predznanja, potrebno je da nastave da uočavaju ULS i njihove funkcije u nizu akademskih konteksta, upoznaju primere ovih spojeva kojima autori postižu još neke dodatne komunikativne namere, kao što su organizacija diskursa ili iznošenje argumenata, kao i da upoznaju druge funkcije koje ovi učestali spojevi mogu imati u akademskom diskursu.

Iako dobijeni rezultati i njihova analiza pokazuju da nakon obrađene nastavne jedinice koja skreće pažnju studenata na formu i funkciju ULS svaki od studenata pojedinačno pokazuje poznavanje barem četiri, a najviše petnaest ciljnih ULS, odgovor na istraživačko pitanje da li nakon obrađene nastavne jedinice studenti mogu 
pravilno da upotrebe ciljne ULS je potvrdan za deo testiranih ULS koji takođe nisu isti ULS kod različitih studenata. Da bi se potvrdila hipoteza $\mathrm{H}_{2}$ da takva nastavna jedinica doprinosi pravilnoj upotrebi kod većine studenata, potrebno je dodatno empirijsko istraživanje koje bi testiralo kompetenciju u upotrebi ULS pre nastavne jedinice i posle nje, i analiziralo rezultate svih studenata zajedno. Neko buduće istraživanje bi moglo da bude nastavak ovog istraživanja i empirijski opovrgne ili potvrdi ovu pretpostavku.

Trebalo bi napomenuti da je ovo istraživanje vršeno na uzorku koji broji 58 studenata, pa bi neka buduća studija mogla da uključi veći broj studenata engleskog jezika u oblasti biotehničkih disciplina, na primer, priključujući uzorku sa Poljoprivrednog fakulteta uzorak sa Šumarskog fakulteta, koji takođe pripada grupaciji biotehničkih. Ovakva dopuna istraživanja imala bi smisla s obzirom na to da Hajland (2008b) pronalazi da se autori iz različitih oblasti oslanjaju na drugačije resurse kako bi obrazložili svoje argumente, zadobili kredibilitet i ubedili čitaoce u ono što zagovaraju, kao i da se konkretni primeri ULS koji su u upotrebi razlikuju između naučnih oblasti, a da studenti oba gore navedena fakulteta savlađuju engleski jezik zajedničke naučne oblasti, odnosno biotehnike.

Krajnji doprinos ovog istraživanja, kada je nastava na fakultetima u pitanju, je to što iz njega možemo zaključiti da učestale leksičke spojeve treba predavati, upoznajući studente sa celim spektrom njihovih funkcija, u kontekstima koje bi mogli da analiziraju, i u diskursu koji je sličan onom sa kojim se susreću svakodnevno tokom svojih studija. Predavačima engleskog za akademske namene ovim radom ukazujemo na značaj ULS kao resursa za kreiranje materijala namenjenih učionici, dok značajan doprinos tom pristupu mogu dati ovakve studije, kao potencijalno korisne za sastavljanje nastavnih materijala namenjenih tačno određenoj naučnoj oblasti, što je u ovom slučaju poljoprivreda, odnosno biotehnika u nešto širem smislu.

\section{Literatura}

Ädel, A., Erman B. (2012). Recurrent word combinations in academic writing by native and non-native speakers of English: A lexical bundles approach. English for Specific Purposes, 31(II), 81-92. https://doi.org/10.1016/j.esp.2011.08.004

Appel, R., Murray, L. (2020). L1 differences in L2 English academic writing: A lexical bundles analysis. Journal of English for Academic Purposes, 46, 100873. https://doi. org/10.1016/j.jeap.2020.100873

Bal, B. (2010). Analysis of Four-word Lexical Bundles in Published Resesarch Articles Written by Turkish Scholars (unpublished doctoral dissertation). Georgia State University, Georgia, USA.

Biber, D. (2009). A corpus-driven approach to formulaic language in English: Multi-word patterns in speech and writing. International Journal of Corpus Linguistics, 14, 275311. https://doi.org/10.1075/ijcl.14.3.08bib

Biber, D., Barbieri, F. (2007). Lexical bundles in university spoken and written registers. English for Specific Purposes, 26, 263-286. https://doi.org/10.1016/j.esp.2006.08.003 
Biber, D., Conrad, S. (1999). Lexical Bundles in Conversation and Academic Prose. In H. Hasselgard \& S. Oksefell (Eds.), Out of corpora: studies in honour of Stig Johansson (pp. 181-190). Amsterdam: Rodopi.

Biber, D., Conrad, S., Cortes, V. (2003). Towards a taxonomy of lexical bundles in speech and writing. In A. Wilson, P. Rayson \& T. McEnery (Eds.), Corpus linguistics by the lune: A festschrift for Geoffrey Leech (pp.71-92). Frankfurt, Germany: Peter Lang.

Biber, D., Conrad, S., Cortes, V. (2004). If you look at . . lexical bundles in university teaching and textbooks. Applied Linguistics, 25, 371-405. https://doi.org/10.1093/ applin/25.3.371

Biber, D., Johansson, S., Leech, G., Finegan, E. (1999). Longman Grammar of Spoken and Written English. Longman: Harlow.

Bychkovska, T., Lee, J. J. (2017). At the same time: Lexical bundles in L1 and L2 university student argumentative writing. Journal of English for Academic Purposes, 30, 3852. https://doi.org/10.1016/j.jeap.2017.10.008

Byrd, P., Coxhead, A. (2010). On the other hand: Lexical bundles in academic writing and in the teaching of EAP. University of Sydney Papers in TESOL, 5, 31-64. https://faculty. edfac.usyd.edu.au/projects/usp_in_tesol/pdf/volume05/Article02.pdf

Chen,Y. H., Baker, P. (2010). Lexical bundles in L1 and L2 student writing. Language, learning and technology, 14, 30-49. https://scholarspace.manoa.hawaii.edu/ bitstream/10125/44213/1/14_02_chenbaker.pdf

Cortes,V. (2002). Lexical bundles in freshman composition. In R. Reppen, S. Fitzmaurice \& D. Biber (Eds.), Using corpora to explore linguistic variation (pp. 131-145). Amsterdam: John Benjamins.

Cortes, V. (2004). Lexical bundles in published and student disciplinary writing: Examples from history and biology. English for Specific Purposes, 23, 397-423. https://doi. org/10.1016/j.esp.2003.12.001

Dontscheva-Navratilova (2012). Lexical bundles in academic texts by non-native speakers. Brno Studies in English, 38(II), 37-58. DOI: 10.5817/BSE2012-2-3

Hyland, K. (2008a). Academic clusters: Text patterning in published and postgraduate writing. International Journal of Applied Linguistics, 18, 41-62. https://doi. org/10.1111/j.1473-4192.2008.00178.x

Hyland, K. (2008b). As can be seen: Lexical bundles and disciplinary variation. English for Specific Purposes, 27, 4-21. https://doi.org/10.1016/j.esp.2007.06.001

Hyland, K. (2012). Bundles in Academic Writing. Annual Review of Applied Linguistics, 32, 150-169. https://doi.org/10.1017/S0267190512000037

Lazić, K. (2017). Učestali leksički spojevi u engleskom jeziku biotehničke struke: Korpusna analiza radova izvornih i neizvornih govornika (neobjavljena doktorska disertacija). Filološki fakultet Univerziteta u Beogradu.

Salazar, D. (2011). Lexical Bundles in Scientific English: A corpus based study of native and non-native writing (unpublished doctoral dissertation). Universitat de Barcelona, Barcelona.

Schmidt, R. W. (1990). The role of consciousness in second language learning. Applied Linguistics, 11, 129-158. https://doi.org/10.1093/applin/11.2.129 


\section{Danijela Đorđević \\ Katarina Lazić}

Summary

\section{TEACHING LEXICAL BUNDLES IN A MASTER'S DEGREE ESP COURSE}

This research paper deals with the use of lexical bundles, i.e. units such as on the other hand or are likely to be in academic discourse, and students' ability to use them properly in a specific context. Introducing academic discourse and its features to students should have a significant place in teaching a foreign language for specific purposes at the university level, since lexical bundles are its important segment. One way of aiding students within a second language learning context is to help them notice and learn these items, making them aware of different contexts in which lexical bundles are used, and of the functions they perform in the discourses of academic disciplines (Schmidt, 1990). The subject of the current study is the use of lexical bundles in the English academic discourse. This research study aims to determine whether students can use lexical bundles properly and whether there is a correlation between the students' English language proficiency and proper use of lexical bundles. The participants of the study were students of a Master's degree programme in Agriculture at the University of Belgrade, Faculty of Agriculture. The test results have revealed proper use of certain lexical bundles for individual students from all proficiency groups. In addition, the most proficient use was found in students with the most advanced knowledge of English. However, these results statistically significantly differed from the results of the groups at intermediate and elementary levels. This implies the need to pay more attention to lexical bundles and their functions in the discourse of a given discipline within a mixed-ability class.

\section{Key words:}

academic discourse, ESP, special-purpose foreign language teaching, master studies, mixed-ability class, lexical bundles 